\title{
Providing an Effective Model of Good Governance Based on the Criteria Proposed by Muslim Thinkers for Organizational Health in Governmental Organizations in Kerman Province
}

\section{Proporcionar un modelo efectivo de buen gobierno basado en los criterios propuestos por los pensadores musulmanes para la salud organizacional en las organizaciones gubernamentales en la provincia de Kerman}

Taherh Safary zadeh Bezenjani

Islamic Azad University, Kerman, Iran.

ORCID: https://orcid.org/0000-0002-0212-7270

Alireza Manzari Tavakoli*

Islamic Azad University, Kerman, Iran.

ORCID: https://orcid.org/0000-0003-4271-782X

Amin Nikpour

Islamic Azad University, Kerman, Iran.

ORCID: https://orcid.org/0000-0001-7559-4980

Received 02-12-20 Revised 02-25-20 Accepted 06-13-20 On line 06-29-20

*Correspondence

Email: a.manzari@iauk.ac.ir
Cite as:
Safary zadeh Bezenjani, T., Manzari Tavakoli, A., \& Nikpour A., Providing an Effective Model of Good Governance Based on the Criteria Proposed by Muslim Thinkers for Organizational Health in Governmental Organizations in Kerman Province. Propósitos y Representaciones, $8 \quad$ (SPE2), e669. Doi: http://dx.doi.org/10.20511/pyr2020.v8nSPE2.669 


\section{Summary}

Good governance is an unavoidable requirement to improve the health of the administrative system in a society. Thus, the purpose of this study is to design an effective model of good governance based on the proposed criteria of Muslim thinkers for organizational health in governmental organizations in Kerman province. Regarding the purpose, this research is applied, it is descriptive of correlational type in terms of nature, and is survey considering method. The statistical population includes all employees and managers working in governmental organizations and offices in Kerman (2310 people). The sample size was estimated to be 321 based on Morgan's table, and were chosen by simple random sampling. A researcher-made questionnaire was used to gather data. The validity of the good governance questionnaire was 94\% based on the proposed criteria of Muslim thinkers and the validity of the organization's health questionnaire was $93 \%$. The reliability coefficient of the questionnaires was calculated to be 0.91 and 0.88; respectively. Spearman correlation test through SPSS software was used to analyze the data. Based on the results at a significant level of less than 0.05 , the correlation coefficients of Spearman between the components of: accountability and the right to express good governance (0.156), political stability and the absence of good governance violence (0.154), the effectiveness of government Good governance (0.122), regulatory quality of good governance (0.238), the authority of good governance law (0.342), and the inhibition of good governance corruption (0.178) and organizational health were positive and significant. Considering that the capacity of a governing system to support the country's macro-strategies and policies for public welfare is increasingly recognized as the basis for the progress and development of society, government officials should double their efforts to solve the problems in the field of health system for achieving the goals of the upstream documents.

Keywords: Good Governance; Organizational Health; Macro-Policies; Law.

\section{Resumen}

La buena gobernanza es un requisito inevitable para mejorar la salud del sistema administrativo en una sociedad. Por lo tanto, el propósito de este estudio es diseñar un modelo efectivo de buen gobierno basado en los criterios propuestos por los pensadores musulmanes para la salud organizacional en organizaciones gubernamentales en la provincia de Kerman. Con respecto al propósito, esta investigación se aplica, es descriptiva del tipo de correlación en términos de naturaleza, y es un método que considera la encuesta. La población estadística incluye a todos los empleados y gerentes que trabajan en organizaciones y oficinas gubernamentales en Kerman (2310 personas). El tamaño de la muestra se estimó en 321 según la tabla de Morgan, y se eligieron mediante muestreo aleatorio simple. Se utilizó un cuestionario realizado por un investigador para recopilar datos. La validez del cuestionario de buena gobernanza fue del 94\% según los criterios propuestos por los pensadores musulmanes y la validez del cuestionario de salud de la organización fue del 93\%. El coeficiente de fiabilidad de los cuestionarios se calculó en 0,91 y 0,88; respectivamente. La prueba de correlación de Spearman a través del software SPSS se utilizó para analizar los datos. Con base en los resultados a un nivel significativo de menos de 0.05 , los coeficientes de correlación de Spearman entre los componentes de: responsabilidad y el derecho a expresar el buen gobierno (0.156), la estabilidad política y la ausencia de violencia de buen gobierno (0.154), La efectividad del buen gobierno (0.122), la calidad regulatoria del buen gobierno (0.238), la autoridad de la ley de buen gobierno (0.342) y la inhibición de la corrupción del buen gobierno (0.178) y la salud organizacional fueron positivas y significativas. Considerando que la capacidad de un sistema de gobierno para apoyar las macro estrategias y políticas de bienestar público del país se reconoce cada vez más como la base para el progreso y el desarrollo de la sociedad, los funcionarios del gobierno deben duplicar sus esfuerzos para resolver los problemas en el campo de sistema de salud para alcanzar los objetivos de los documentos anteriores. 
Palabras clave: Buen gobierno; Salud Organizacional; Macropolíticas; Derecho.

\section{Introduction}

When people enter an organization, they are affected by miscellaneous internal and external organizational, political, social, economic and cultural factors, and their individual and work personality is formed and evolved. In the meantime, there are people who are negatively affected by various factors and commit organizational and work unconformities and violations in various ways that this issue damages on the health of the administrative and organizational system and has adverse effects on the process of work, production and behavior of other people. What causes and factors specifically provide organizational health, requires research, but, examining and clarifying the consequences of the lack of organizational health is an issue that is caused by violations and is one of the main issues that makes it more definite and serious to find the root of violations in those involved and organizational executives (WEKILING \& lynden, 2000).

Health means the absence of disease and failure in an organism (living creature). On the other hand, being free from disease does not mean that the body is functioning optimally because the organism may be healthy but does not perform its duties and functions (Darmangar, 2009).

Administrative corruption is considered one of the chronic and in fact the oldest injuries in the administrative system, because it is a permanent phenomenon accompanying the government. That is, when human activities took an organized form, administrative corruption also emerged from the organization's inner side through internal interactions with the environment (Mauro, 2005). Lack of the administrative and organizational system health in a country can have many negative effects and consequences, including the destruction of economic and social structures, blockage or limitation in the country's development path, reduction in public services to society, prevention from trade and investment growth, prevention from the realization of democracy, people's distrust toward the government and the ruling system, wasting valuable economic resources, the government's failure to achieve its goals, negative impact on GDP growth, reduction in foreign investment, increasing income inequality and poverty and injustice (Wayne \& Feldman, 2002).

Now the question is, can the concept of health, which is related to living beings, be used for organizations as well? Miles believes that regardless of the problems that considering the organization as an organism and the type of being ideal bring to the concept of perfect health, the organizational health approach has significant scientific advantages in terms of the concept of organizational dynamics and examinations and efforts to improve them (Martin \& Sandra, 2005). The concept of organizational health is a unique concept that allows us to have a great image of organizational health. In healthy organizations, the employees are committed, conscientious, and helpful, and have high morale and performance (Yap Kioe, 2010). The results of conducted studies and research indicate that there is a lack of organizational health in various forms in the country's administrative apparatus, and in spite of all the efforts made, the observing organizations have not been able to deal with it. Thus, the Islamic Republic of Iran has made serious and extensive efforts to improve the health of the administrative and organizational system, as well as prevent corruption and struggle decisively against it (Shahabadi \& Jameh Bozorgi, 2013).

One of the basic strategies to solve many problems is paying attention to Islamic management and studying and applying the theories and principles of this school. The explicit precepts of islam in the years preceding the idea of good governance have been deliberated in the Qur'an and religious teachings. And over the centuries, western philosophy has presented it as a human achievement and a prerequisite for all-inclusive development (Taghavi Damghani, 2019). 
Religious teachings and the school of Islamic management have recurrently referred to the phenomenon of good governance. The explicit advice of the Qur'an, narrations and hadiths indicate the antiquity and historical background of the idea of good governance in Islam. On the other hand, since in the general policies of the administrative system transferred by the Supreme Leader, it has been emphasized on implementing Islamic values in the existing social institutions in the society and also on the promotion of the administrative system health and the efficiency of monitoring and controlling structures in the administrative system (Paragraphs 24 and 25 of the general policies of the administrative system), management with an Islamic approach is one of the aspirations of this system. In Islamic resources and teachings, there are clear instructions on the method of governing in order to prevent deviations in them. Muslim thinkers emphasize on effective management and good governance in clarifying the teachings of the Islamic religion for effective interaction between with the society institutions (Sardarnia, 2010).

Islam has its own special methods for the proper governance of its organizations and establishments, which cannot be found in any system except the school of the prophets (Sardarnia, 2010). In Islam, the manager, in addition to providing the conditions for employees to always see themselves in the presence of God Almighty and to serve humanity through internal supervision in the way of God, and to do things right, it must provide the conditions for it to be able to take care of things by exercising accurate governance, because there are some who may not observe the spiritual and divine standards (Taghavi Damghani, 2019).

The summary obtained from the review of studies on the indicators of good governance from different perspectives indicates that good governance can be divisible in the form of accountability and the right to comment, political stability and the absence of violence, government effectiveness, regulatory quality, administration of law and corruption control.

On the other hand, examples of organizational health include non-discrimination, nonabuse, the absence of job violations, non-violation of the law and the lack of tolerance and toleration (Rudra \& Sanyal, 2011).

With these explanations, the main issue of the present study is to provide an effective model for good governance based on the proposed criteria of Muslim thinkers for organizational health in governmental organizations in Kerman province.

\section{Conceptual Model}

A lot of research studies have been conducted on two variables of criteria and predictions in the country and out of it, but foreign resources are somewhat richer than the existing national resources because of paying more attention to organizational health in developed countries. Considering the extensive study and discovery and reference to documents, the research that explicitly examined the relationship between the structural dimensions of the organization and organizational health in government organizations was not found, thus, all the studies separately conducted have examined the relationship between the structural dimensions of the organization and the organizational health, which are mentioned below (Figure 1): 


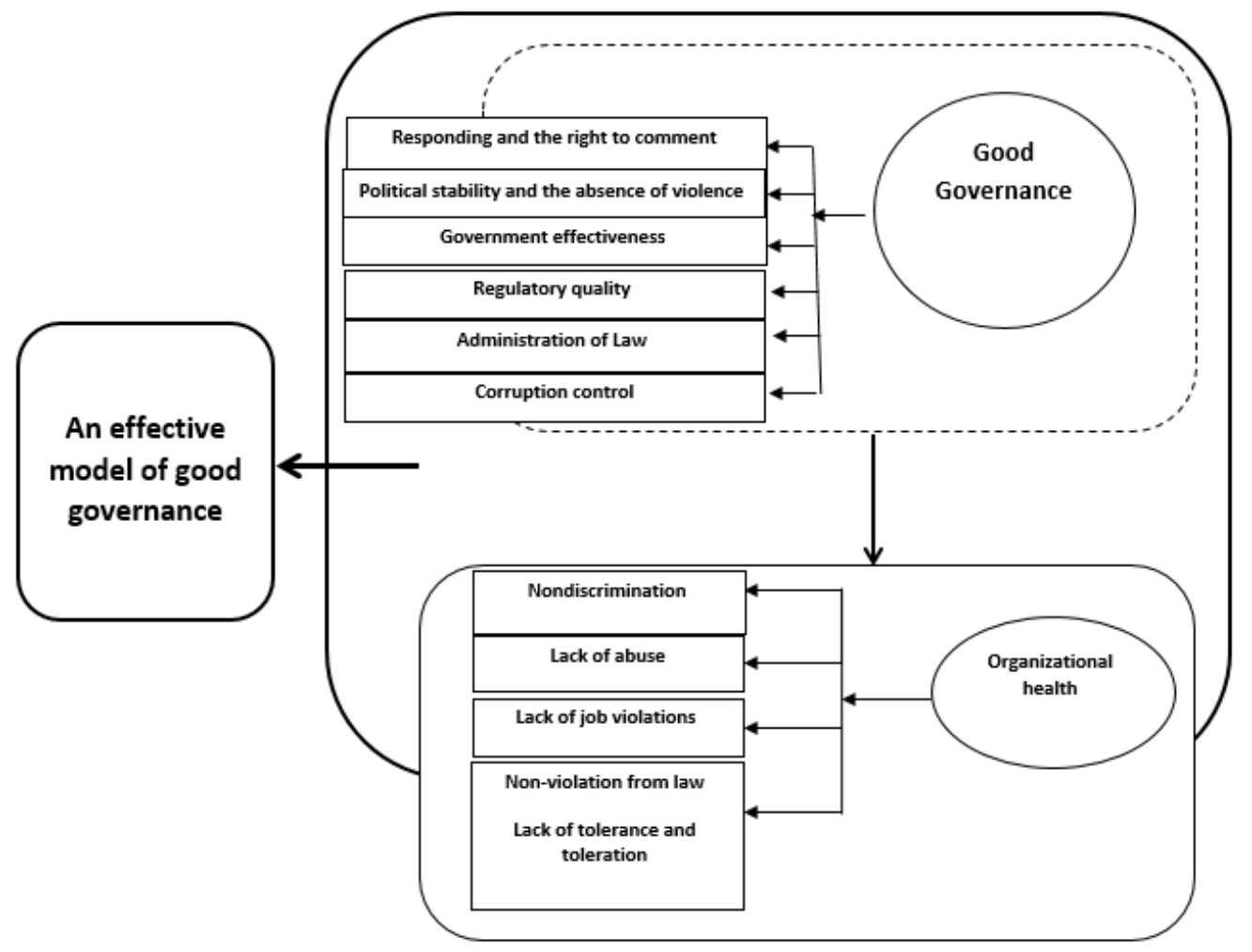

Figure 1. Conceptual Model

\section{Method}

In terms of purpose, this research is applied, and in terms of nature, it is descriptive of correlational type, and in terms of method, it is of survey type. The statistical population of this study includes all employees and managers working in governmental organizations and departments in Kerman, the number of them was 2310 . The number of organizations is based on the data presented by the planning deputy of Kerman governorate in 2017. Morgan's table was used to determine the sample size, according to which the sample size is 321 people who are selected by simple random method. Two questionnaires were used to collect information. The Good Governance Questionnaire was based on the criteria proposed by Muslim thinkers and included 38 questions and included components of: government accountability, political stability, lack of violence, government effectiveness, regulatory quality and administration of law, and corruption control. The Organizational Health Questionnaire has 19 questions in the form of components of: nondiscrimination, non-abuse, non-violation, non-violation of the law, and lack of tolerance and toleration. The questions were arranged in a 5-point Likert scale from very low to very high. To determine the validity, the questionnaires were given to 30 experts to give their ideas on the appropriateness of the questionnaire, after the performing the calculations, the validity of the good governance questionnaire was $94 \%$ based on the proposed criteria of Muslim thinkers and the validity of the organization's health questionnaire was $93 \%$. Cronbach's alpha method was used to determine the reliability. Based on the proposed criteria of Muslim thinkers, the reliability coefficient of the good governance questionnaire was calculated to be 0.91 , and the reliability coefficient of the organizational health questionnaire was 0.88. In the current study, Spearman correlation test using SPSS software was used to analyze the data. 


\section{Results}

The main hypothesis: There is a relationship between good governance and organizational health.

Considering the fact that the normality test statistic is 99.294 and the p-value is less than 0.001 , the organizational health variable does not have a normal distribution, and therefore, Spearman and Kendall correlation tests were used. Based on the results given in (Table 1), the correlation coefficient of Spearman is 0.326 , the correlation coefficient of Kendall is 0.232 and the p-value is less than 0.001 . Therefore, the null hypothesis is rejected at the level of 0.05 . So, there is a relationship between good governance and organizational health.

Table 1.

Correlation Test of Good Governance and Organizational Health

\begin{tabular}{cc}
\hline Spearman correlation coefficient & 0.326 \\
\hline Kendall correlation coefficient & 0.232 \\
\hline Number & 321 \\
\hline p- value & Less than 0.0005 \\
\hline
\end{tabular}

Sub-hypothesis (1): There is a relationship between the component of accountability and the right to express one's opinion on good governance and organizational health. Based on the results given in (Table 2), the correlation coefficient of Spearman is 0.156 and the coefficient of Kendall correlation coefficient is 0.122 and p-value is 0.005 , so the null hypothesis is rejected at the level of 0.05 . So there is a relationship between the component of accountability and the right to express one's opinion and good governance and organizational health.

Table 2.

Correlation Test of the component of accountability and the right to express one's opinion on good governance and organizational health

\begin{tabular}{cc}
\hline Spearman correlation coefficient & 0.156 \\
\hline Kendall correlation coefficient & 0.112 \\
\hline Number & 321 \\
\hline p- value & Less than 0.0005 \\
\hline
\end{tabular}

Sub-hypothesis (2): There is a relationship between the component of political stability and the absence of violence and good governance and organizational health.

According to the results of (Table 3), the correlation coefficient of Spearman is 0.154 and the correlation coefficient of Kendall correlation is 0.105 and p-value is 0.006 , so the null 
hypotheses is rejected at the level of 0.05 . Thus, there is a relationship between the component of political stability and the absence of violence and good governance and organizational health.

Table 3.

Correlation Test of a component of political stability and the absence of violence and good governance and organizational health

\begin{tabular}{cc}
\hline Spearman correlation coefficient & 0.154 \\
\hline Kendall correlation coefficient & 0.105 \\
\hline Number & 321 \\
\hline$p$ - value & Less than 0.0006
\end{tabular}

Sub-hypothesis (3): There is a relationship between the government effectiveness component and good governance and organizational health.

Based on the results of (Table 4), the correlation coefficient of Spearman is 0.178 and the coefficient of Kendall correlation is 0.122 and p-value is 0.001 , so the null hypotheses is rejected at the level of 0.05 . So there is a relationship between the component of government effectiveness and good governance and organizational health.

Table 4.

Correlation test of the component of effectiveness and good governance and organizational health

\begin{tabular}{cc}
\hline Spearman correlation coefficient & 0.178 \\
\hline Kendall correlation coefficient & 0.122 \\
\hline Number & 321 \\
\hline p- value & Less than 0.0001 \\
\hline
\end{tabular}

Sub-hypothesis (4): There is a relationship between the component of regulatory quality and good governance and organizational health.

Based on the results of (Table 5), the correlation coefficient of Spearman is 0.238 and the correlation coefficient of Kendall is 0.172 and p-value is less than 0.001 , so the null hypotheses is rejected at the level of 0.05 . So there is a relationship between the component of regulatory quality and good governance and organizational health.

Table 5.

Correlation test of the component of regulatory quality and good governance and organizational health

\begin{tabular}{cc}
\hline Spearman correlation coefficient & 0.238 \\
\hline Kendall correlation coefficient & 0.172 \\
\hline Number & 321 \\
\hline
\end{tabular}




$$
\text { p- value Less than } 0.0001
$$

Sub-hypothesis (5): There is a relationship between the administration of law and good governance and organizational health.

Based on the results of (Table 6), the correlation coefficient of Spearman is 0.342 and the correlation coefficient of Kendall is 0.249 and p-value is less than 0.001 , so the null hypotheses is rejected at the level of 0.05 . So there is a relationship between the administration of law and good governance and organizational health.

Table 6.

Correlation test of the component of the administration of law and good governance and organizational health

\begin{tabular}{cc}
\hline Spearman correlation coefficient & 0.342 \\
\hline Kendall correlation coefficient & 0.249 \\
\hline Number & 321 \\
\hline p- value & Less than 0.0001
\end{tabular}

Sub-hypothesis (6): There is a relationship between the component of controlling corruption and good governance and organizational health.

Based on the results of (Table 7), the correlation coefficient of Spearman is 0.178 and the coefficient of Kendall correlation is 0.122 and p-value is 0.001 , so the null hypothesis is rejected at the level of 0.05 . So there is a relationship between the component of controlling corruption and good governance and organizational health.

\section{Table 7.}

Correlation test of the component of controlling corruption and good governance and organizational health

\begin{tabular}{cc}
\hline Spearman correlation coefficient & 0.178 \\
\hline Kendall correlation coefficient & 0.122 \\
\hline Number & 321 \\
\hline p- value & $0.001^{*}$ \\
\hline
\end{tabular}

The fitness indicators of the structural equation model to the final research model have been indicated in (Table 8) that based on all the mentioned indicators, the final research model is approved and appropriate (Figure 2). 


\section{Table 8.}

The results of the structural equation model of the final research model

\begin{tabular}{ccccccccc}
\hline $\begin{array}{c}\text { Indicator } \\
\mathrm{s}\end{array}$ & $\begin{array}{c}\text { RMSE } \\
\mathrm{A}\end{array}$ & CFI & TLI & IFI & GFI & $\begin{array}{c}\text { RMR } \\
\text { CMIN/ } \\
\text { DF }\end{array}$ & P \\
\hline $\begin{array}{c}\text { Before } \\
\text { making } \\
\text { reforms }\end{array}$ & 0.098 & 0.86 & 0.81 & 0.86 & 0.79 & 0.49 & 3.43 & 0.000 \\
\hline $\begin{array}{c}\text { After } \\
\text { making } \\
\text { reforms }\end{array}$ & 0.093 & 0.90 & 0.88 & 0.90 & 0.81 & 0.043 & 3.202 & 0.000 \\
\hline $\begin{array}{c}\text { Accepta } \\
\text { ble level }\end{array}$ & $<0.1$ & $>0.90$ & $>0.90$ & $>0.90$ & $>0.90$ & $<0.05$ & $<5$ & $>0.05$ \\
\hline Result & $\begin{array}{c}\text { inappr } \\
\text { opriate }\end{array}$ & $\begin{array}{c}\text { approp } \\
\text { riate }\end{array}$ & $\begin{array}{c}\text { inapprop } \\
\text { riate }\end{array}$ & $\begin{array}{c}\text { approp } \\
\text { riate }\end{array}$ & $\begin{array}{c}\text { approp } \\
\text { riate }\end{array}$ & $\begin{array}{c}\text { approp } \\
\text { riate }\end{array}$ & $\begin{array}{c}\text { appropri } \\
\text { ate }\end{array}$ & $\begin{array}{c}\text { inappro } \\
\text { priate }\end{array}$ \\
\hline
\end{tabular}

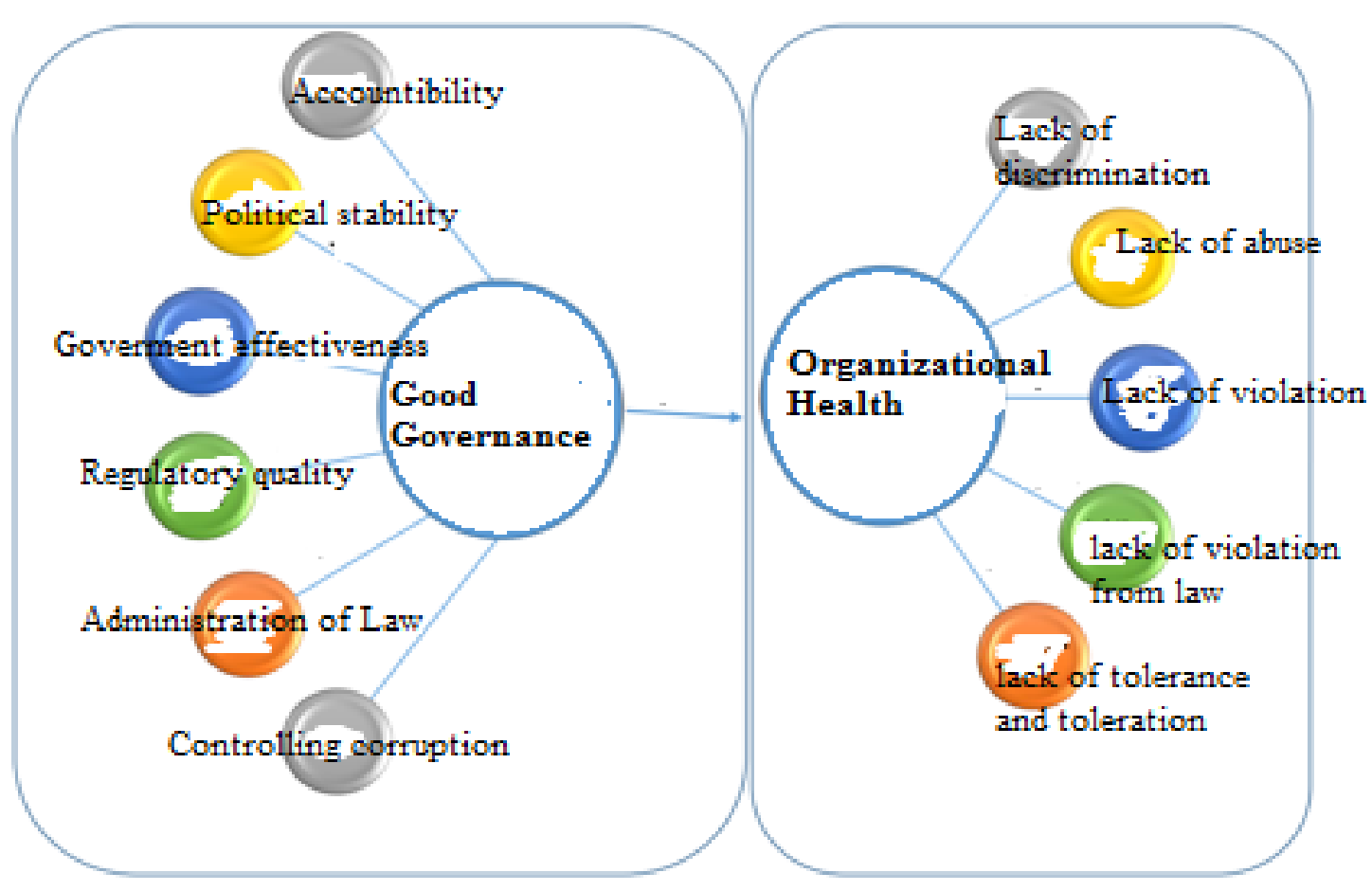

Figure 2. The final model of an effective pattern of good governance for organizational health in governmental organizations in Kerman province 


\section{Discussion}

The findings of the current study presented that there is a significant and direct relationship between good governance from the perspective of Muslim thinkers and the health of the organization. Tabarsa in their research, concluded that one of the factors affecting the health of the organization is good governance (Tabarsa, 2012), which is consistent with the findings of the present study.

The findings of the current study indicated that there is a significant and direct relationship between the component of government accountability and the variable of good governance from the perspective of Muslim thinkers with organizational health. In their research Jalaei et al. concluded that one of the requirements to achieve organizational health is the obligating governments and organizations to give power to the people for employing and the need to respond to them (Jalaei et al., 2017), which is consistent with the findings of the current study.

The findings of the present study indicated that there is a significant and direct relationship between the component of participation and the right of people to express their opinion on the variable of good governance from the perspective of Muslim thinkers and organizational health. In his research, Sadeghi \& Moinabadi concluded that the health of the administrative system of societies should be considered as a dependent variable that is affected by the conscious vote of the people in elections (Sadeghi \& Moinabadi, 2013), which is consistent with the findings of the present study.

The findings of the current study displayed that there is a significant and direct relationship between the component of political stability from the variable of good governance from Muslim thinkers' point of view and organizational health. In his field research, Sameti \& Mohseni found that avoiding negative and destructive rumors has a positive effect on the implementation of health programs in the administrative system (Sameti \& Mohseni, 2011), which is consistent with the findings of the current study.

The findings of the current study presented that there is a significant and direct relationship between the lack of violence from the variable of good governance from the perspective of Muslim thinkers and the organizational health. Razmi \& Sedighi, in his research, concluded that avoiding social conflicts and mass strikes affects on the health of the organization (Razmi \& Sedighi, 2014), which is consistent with the findings of the present study.

The findings of the present study indicated that there is a significant and direct relationship between the component of government effectiveness of the variable of good governance from the perspective of Muslim thinkers and the organizational health. Alvani \& Alizadeh Sani stated receiving the attention of officials in achieving the goals set out in the upstream documents of the country, facilitates the improvement of the health levels of a civil society (Alvani \& Alizadeh Sani, 2007), which is consistent with the findings of the current study. The findings of the current study presented that there is a significant and direct relationship between the component of regulatory quality and the variable of good governance from the perspective of Muslim thinkers and the organizational health. Arabshahi, in his research concluded that periodic monitoring of the implementation of instructions, regulations, etc. in the organization, guarantees the promotion of the health of the administrative system (Arabshahi, 2005), which is consistent with the findings of the current study.

The findings of the current study indicated that there is a significant and direct relationship between the component of the administration of law from the variable of good governance from the point of view of Muslim thinkers and the organizational health. In his research, Sardarnia found out respecting and following law enforcement and social law enforcement agencies at the 
organizational level, is the prerequisite for promoting community health (Sardarnia, 2010), which is consistent with the findings of the present study.

The findings of the present study indicated that there is a significant and direct relationship between the component of preventing corruption from the variable of good governance from the perspective of Muslim thinkers and organizational health. Faiz \& Shahabi, found out that the laws against corruption and legal rents have a direct and significant relationship with the health efficiency of the administrative system (Faiz \& Shahabi, 2010), which is consistent with the results of the current study.

\section{Conclusion}

Considering the direct and significant relationship between the two main variables of research, ie good governance based on the proposed criteria of Muslim thinkers and the organizational health in the governmental organizations in Kerman province, it is recommended given that the capacity of a governing system to support the country's macro-strategy and policies for public welfare, it is increasingly recognized as the foundation for the progress and development of society. Governmental officials should double their efforts to achieve the goals of the upstream documents to solve the problems in the field of health system. Regarding the importance and priority of the component of regulatory quality, it is recommended that macro-policies be institutionalized in order to standardize the administrative system within the existing organizations in society. Considering the direct and significant relationship between the component of government accountability and good governance variable, it is suggested that periodic monitoring of facilitation of public access to the organizational officials be put on the agenda. Regarding the direct and significant relationship between the component of participation and the right of the people to express their views on the good governance variable, it is suggested to pave the way for the creation of a peaceful atmosphere in which the people's conscious vote in the elections is encouraged and also, the level of diligence of government officials on behalf of the people and organizations in explaining and providing vital and welfare issues of the country should be observed and monitored. Considering the direct and significant relationship between the component of political stability and the good governance variable, it is suggested that the legal process of gaining power in organizations gain a legal and logical process to avoid political fever and leadership of the intellectual group in organizational strategic affairs as much as possible. Based on the results of the direct and significant relationship between this component and the absence of violence from the variable of good governance is suggested. Organizations take a rational and cautious approach to organized extremism, avoiding destructive tensions in the formation of all kinds of organizational strikes. Considering the result of a direct and significant relationship between the component of government effectiveness and good governance variable, it is suggested that the authorities make a double effort to protect the public interest and move in the direction of the law to achieve the goals set out in the upstream documents. Considering the result of a direct and significant relationship between the component of regulatory quality and the good governance variable, it is suggested that the standardization of the administrative system and the monitoring of the efficiency of the administrative system be examined. Considering the result of a direct and significant relationship between the administration of law component and the good governance variable, it is suggested that culture building is respected and examined as a tool for disciplining and following the law as a social discipline tool and that the level of people's trust in law enforcement in the organization is monitored. Considering the result of a direct and significant relationship between the component of corruption control and the good governance variable, it is suggested that the effectiveness of the application of laws against corruption and legal rents in the organization to be continuously investigated. 


\section{References}

Wekiling w. \& lynden j. (2000), superuising organization Health, supervision journal, 13(14), 35.

Darmangar A. (2009), Health Survey in the Administrative System, a collection of specialized management articles, taken from, 26(3), 175-184.

Mauro P. (2005), Corruption and Growth, Quarterly Journal of Economics, 11(6), 87-98.

Wayne K. \& Feldman J. (2002), organizational Health Measure, journal of Research and the concept its development in Education, 4(5), 30-39.

Martin L. \& Sandra K. (2005), Improving work life quality: A Diagnostic approach model, Bluewater health Magazine, 21(22), 37-39.

Yap Kioe S. (2010), What Is Good Governance? United Nations, Economic \& Social Commission For Asia and The Pasific, 6(8), 312-322.

Shahabadi A. \& Jameh Bozorgi A. (2013), Theory of good governance from the perspective of Nahj al-Balaghah. First year, 2(1): 9-28.

Taghavi Damghani R. (2019), An Overview of Islamic Management, Tehran: Islamic Propaganda Publications, Tenth Edition, 15(1), 56-72.

Sardarnia K. (2010), Moral Civil Society and Human Rights Foundation and Good Governance, Political-Economic Quarterly (in Persian), 25(9), 132-259.

Rudra P. \& Sanyal G. (2011), Good Governance and Human Development: Evidence from Indian States, Journal of Social and Development Sciences, 1(1), 1-8.

Tabarsa N. (2012), University and Industry Relations: Win and Lose, Tehran: National Conference on Entrepreneurship and Knowledge-Based Business Management, 6(5), 1723.

Jalaei A. \& Derakhshandeh S. \& Eskandari Sabz S. (2017), A Study of the Impact of Good Governance on the Relationship between Industry and University, 2013, Proceedings of the Second Conference on Industrial and University Interaction. Kerman: Kerman Chamber of Commerce, Industries, Mines and Agriculture, 25(9), 45-59.

Sadeghi H. \& Moinabadi A. (2013), The position of research parks in the country's research system, Conference on Future Science and Technology and Strategies, 11(5), 85-97.

Sameti M. \& Mohseni F. (2011), Analysis of the Impact of Good Governance Indicators on the Human Development Index (Case Study: Southeast Asian Countries). Journal of Economic Growth and Development Research, First Year, Fourth Issue, 8(4), 59-73.

Razmi M. \& Sedighi S. (2014), Requirements for Realization of Good Governance to Achieve Human Development. 4th National Conference on Iranian Economy, Islamic Azad University, Khomeinishahr Branch, 16(3), 7-62.

Alvani M. \& Alizadeh Sani M. (2007), An Analysis of the Quality of Good Governance in Iran, Quarterly Journal of Management Studies, 8(5), 23-40.

Arabshahi S. (2005), Development Management, Second Edition, Tehran: Ostadi Publications, 17(1), 257-263.

Faiz A. \& Shahabi A. (2010), Evaluation and prioritization of university and industry communication barriers (case study of Semnan city). Quarterly Journal of Leadership and Educational Management, Islamic Azad University, Garmsar Branch, Fourth Year, 2(6): 124-138. 